\title{
Loneliness and Psychological Well-Being on International Students of the Darmasiswa Program Universitas Negeri Yogyakarta
}

\author{
Mawas Dwi Cabyadi1 \\ ${ }^{1}$ Department of Psychology, Universitas Negeri Yogyakarta, \\ Jl. Colombo No. 1 Karang Malang Sleman, Yogyakarta \\ ${ }^{1}$ mawascahyadi@gmail.com
}

\begin{abstract}
This research aims to describe and find out the correlation between loneliness and the psychological well-being of international students of the Darmasiswa program at Yogyakarta State University. This research uses descriptive quantitative methods and data sources are obtained based on instruments that are distributed to 20 research subjects the international students. The research data were collected with the UCLA Loneliness Scale and Psychological Well Being Scale instruments which were then analyzed using SPSS 22.0 with the Pearson Product Moment correlation test. The results showed that there was a very weak negative relationship $(r=-0.152)$ between loneliness and the psychological well-being of Darmasiswa students at Yogyakarta State University. Most research subjects have low levels of loneliness and moderate psychological wellbeing. There are two dimensions of psychological well-being that have the highest relationship with loneliness, namely environmental mastery $(-0,338)$ and positive relationships with others $(-0,299)$.
\end{abstract}

Keywords: loneliness, psychological well being, international students

\section{Introduction}

The Indonesian government has a program organized by the collaboration with the Ministry of Education and Culture (Kementerian Pendidikan dan Kebudayaan) and the Ministry of Foreign Affairs (Kementerian Luar Negeri) named the Darmasiswa scholarship program. This program is intended for international students from abroad who want to study about Indonesia in the fields of language, culture, and arts. Data on the Darmasiswa official website shows that the interest of international students to take part in this scholarship program is always increasing from year to year. In 2008 the number of participants in the program was around 500 students, and until in 2014, around 700 students were participating (http://darmasiswa.kemdikbud.go.id/abou t-us-2/ , accessed on January 23, 2019). In implementing the program, Darmasiswa participants can choose one of around 50 institutions in Indonesia to learn the language, culture, and arts at their chosen place.

Yogyakarta is one of the choices of the Darmasiswa program with the aim of learning language, culture, and arts. Seven institutions in Yogyakarta hold the Darmasiswa program and each institution emphasizes one of these aspects. One of the institutions that run the Darmasiswa program is Universitas Negeri Yogyakarta (UNY).

The lessons for Darmasiswa students that conducted at UNY consist of Indonesian lectures, tutorial classes, sit-in subjects of interest, art workshops, and cultural excursions. Teachers in the program are lecturers of language courses and UNY students who become tutors or student volunteers.

International students of the 2018/2019 Darmasiswa program at UNY were 21 students. They come from the continents of Asia, Africa, Europe, and America. Darmasiswa students at UNY take Indonesian language classes (BIPA) 


\section{Loneliness and Psychological .... Mawas Dwi Cahyadi}

along with other international students from scholarship and regular programs. The language classes given are in the form of large classes and small classes based on their level of language skills. Whereas in the selected sit-in class, international students attend regular lectures on campus using Indonesian as an introduction.

Becoming a student in another country is a challenge for Darmasiswa students. Cultural differences and social conditions are the main problems that must be faced when becoming a international student. Cultural behaviors that brought by the international students to Indonesia may not be able to adapt to the existing cultures, this is because the international students who move to other countries certainly bring values, beliefs, habits, and behavior from their home countries (Wijaya, 2013). Therefore, being an international student in another country requires good social skills and adaptation.

The adaptation is related to the problem-solving mechanism that is carried out to meet the needs of life. Adaptation is one of the social abilities in overcoming problems that occur in different environments and social conditions. Therefore, the struggle for international students is needed in the adaptation process. Wardani Research (2016) describes the struggle of international students who study at UIN Sunan Kalijaga. In her research, it was concluded that some international students who have a less social interest in establishing relationships with local (Indonesian) students. Low social interest shows the lack of individual interest to establish social relationships, which can also be called low social desirability.

Social desirability is the need of individuals on trying to be accepted in their social environment (Sjostorm, 2002). Generally, individuals tend to show high social desirability in social life. Therefore, low social desirability will show that individuals have deficiencies in social relationships, one of which is a sense of loneliness.

Russell (1996) states the aspects that affect loneliness in an individual consist of Personality, Social Desirability, and Depression. Based on Russell's theory and explanation of Wardani's research, it can be said that individuals with low social desirability tend to be lonely.

Loneliness is a feeling that someone has when the expected relationship is different from what happened (Archibald in Baron, 2000). Loneliness is generally related to social conditions. The research from Wardani indirectly shows that some international students tend to feel lonely.

Loneliness is usually experienced by individuals who find it difficult to adapt, such as new students when starting a new campus life. This is also evidenced by the research from Prasetia (2013) who found a significant relationship between loneliness and adjustment in first-year students.

Based on the results of Prasetia's research, it can be said that if students have difficulty adjusting in their first year, this will also be experienced by the international students who have different socio-cultural backgrounds. We also found another example of an international student who studies in Indonesia. $\mathrm{He}$ is a Pakistani student who claims to have difficulty adapting to his social circumstances. He complained about the lack of language skills, differences in food taste, and the environment. This had made him depressed and feel lonely.

In addition to the case phenomenon, a BIPA (Indonesian Language for Foreign Speakers) lecturer stated that there were international students who had difficulty joining other students. Some tutors also stated that there were international students who always looked depressed, silent, and alone. Lecturer and tutors' concerns lead to the possibility that the student feels lonely due to a lack of adaptability and cultural differences. 


\section{Loneliness and Psychological .... Mawas Dwi Cahyadi}

Cultural problems experienced by international students seem to be a separate topic for the institutions that handle them. An example about the case with international students in Canada. Reported on the social media news site "Study International News" with the title "Canada: International students want more support report"

(https://www.studyinternational.com/new s/canada-international-students-wantmore-support-report , accessed on 9 February 2019), states that most international students studying in Canada have social and academic problems, such as difficulties in blending into campus life and the local community. The news states that the problem affects its well-being, so international students often feel ignored and discriminated against.

Other problems also occur in the United States. The social media news "University World News" reports on institutional efforts in dealing with the psychological problems of international students in America. The page uploaded under the title "How does the university improve international students' wellbeing?"

(https://www.universityworldnews.com/p ost.php?story $=2015021114351336$

accessed on 8 February 2019) International students there tend to feel problems in their mental state. However, the institution assists to international students academically, financially, and interpersonally. These efforts get good results so that international students can reduce psychological problems.

From the two news stories delivered above, it can be concluded that the problem that is often experienced by international students globally is psychological problems. Many international students who study in other countries feel they don't get what they want. This has an impact on their wellbeingness, we argue that this will also have an impact on the psychological well-being of international students.
The explanation of the case above explains that international students in Indonesia can also feel these two problems, namely loneliness and low well-being. However, most cases that are always highlighted in international students are cases of loneliness in which by Myers (1999) it has been explained that chronically lonely individuals seem to be trapped in self-failure in social cognition and social behavior.

The lonely case that is captured is an example of a case that often occurs with international students. Such cases are also common in individuals during an intermediary or a period of environmental change. In general, loneliness is caused by individual internal factors. One of them is the ability to accept himself whether he can understand what he has. Ulfah (2012) examined the relationship between loneliness and self-acceptance. The results of her study stated that there is a significant negative relationship between the two. The higher the self-acceptance that an individual has, the lower the loneliness he feels, and vice versa.

Self-acceptance is the feeling of being satisfied with yourself with the qualities and talents that are owned, as well as the recognition of strengths and weaknesses (Chaplin, 2011). Self-acceptance also requires a positive attitude to him/herself (Ryff, 2008). Ryff explained that selfacceptance, in general, is self-confidence and positive thinking about oneself. This explanation leads to the psychological condition of the individual as well. The ability to accept yourself (self-acceptance) is also included in the dimensions of Ryff's theory of psychological well-being (PWB).

Ryff (1989) explains psychological well-being as the realization and full achievement of individual potential where he can accept the weaknesses and strengths in himself. The dimensions in psychological well-being according to Ryff are selfacceptance (SA), positive relationships with others (PR), autonomy (A), environmental mastery (EM), life goals (LG), and personal 


\section{Loneliness and Psychological .... Mawas Dwi Cahyadi}

development (PD). Individuals with good psychological well-being will have the ability to choose and create an environment that is by with their physical condition (Liwarti, 2013). So, it can be said that psychological well-being plays an important role in the lives of individuals to get a good and comfortable psychological state.

Research on psychological well-being is mostly done in Indonesia. This type of research that is often found is a quantitative research that gets data based on the results of instruments or test kits. Nevertheless, there are also several qualitative studies conducted to determine the psychological well-being of a person. The study uses interview guidelines based on psychological well-being theory.

Most qualitative psychological wellbeing studies describe their well-being by presenting analyzes in each dimension. The results of the interview method usually explain the state of each dimension of psychological well-being with the forms of behavior and feelings experienced by the subject.

Individuals with good psychological well-being can understand their condition, both internal and external. Aisah's research (2017) found that $75 \%$ of the 300 initial students at a university in Yogyakarta had a high level of psychological well-being. The study also linked psychological well-being to the factors of origin of residence divided into two groups, namely Java and outside Java. The results show that there is no difference in the level of psychological wellbeing between students outside Java and Javanese students.

The results of the study by Aisah showed that students with the same country culture did not have differences in the level of psychological well-being they had. Meanwhile, Ryff explained that the different social-cultural orientations in each country are different and can affect the psychological well-being of each individual (Rahayu, 2008). Based on this, it can be said that international students who have different cultural orientations with Indonesia are likely to be affected by their level of psychological well-being.

Psychological well-being can be identified by certain tests and assessments. There are many studies conducted to determine the psychological well-being of individuals and groups. Research on psychological well-being is usually associated with internal conditions in individuals such as resilience, gender roles, social abilities, and others.

Researching individual conditions is an ethical way to understand a theory, for example examining loneliness and the ability to understand themselves or psychological well-being. Researchers are interested in examining loneliness because the problem often occurs in every individual as the case has been described previously. Therefore, researchers raise the research of Cecen and Cenkseven (2007) regarding the relationship of psychological well-being with loneliness. The conclusion of the study shows that there is a negative and significant relationship between psychological well-being and loneliness, ie if the level of loneliness is low then the level of psychological well-being is high, and vice versa.

Loneliness is a negative state that is felt by individuals, whereas psychological well-being is the ability of individuals to regulate themselves in positive situations. This journal describes the problem of loneliness and psychological well-being. Supporting studies used in the preparation of this journal use research with student subjects because the research can be used as a theoretical reference and comparison of the results of the analysis.

The students as a subject are quite a consideration in researching loneliness, especially in international students who have different cultural and social backgrounds. This problem can also be experienced by Darmasiswa program students from outside Indonesia with different national origins. Also considering 


\section{Loneliness and Psychological .... Mawas Dwi Cahyadi}

that the scholarship program aims to understand Indonesia, including social conditions that occur and are experienced while in Indonesia.

This is the background of the researchers to research to Darmasiswa program students at Yogyakarta State University to find out the level of loneliness and psychological well-being, and the relationship between the two.

\section{Methods}

This study is a quantitative descriptive research, using correlation analysis as additional analysis. The research was conducted for 6 months from February to July 2019, conducted at Universitas Negeri Yogyakarta.

\section{Participants}

This study involves the entire population of international students in the Darmasiswa scholarship program at Universitas Negeri Yogyakarta during the academic year 2018/2019 with a total of 20 international students. Population research is considered to be normally distributed and homogeneous, therefore it does not require a significance test.

\section{Data Collection Technique}

Data collection techniques in this study used instruments in the form of official research scales namely the UCLA loneliness scale and psychological welbeing scale.

\section{Data Analysis}

Data analysis techniques used in this study are descriptive analysis techniques and correlative testing. Statistical methods are used to find out the mean, frequency, and minimum-maximum values. Data calculations are also performed to find out the categorization by value.

Table 1. Categorization

\begin{tabular}{ll}
\hline Categories & Formulas \\
\hline High & $x>\mu+1 \sigma$ \\
Moderate & $\mu-1 \sigma<x<\mu+1 \sigma$ \\
Low & $x<\mu-1 \sigma$ \\
\hline$\mu$ : mean; $\sigma$ : standard deviation
\end{tabular}

Correlation analysis conducted in this study was processed using SPSS 22.0 using Pearson Product Moment Correlation to determine the value of the relationship between variables determine the value of the relationship between variables.

\section{Findings and Discussion}

\section{Participant's Characteristics}

The Correlation test conducted in this study was processed with SPSS 22.0 using Pearson Product Moment Correlation to determine the value of the relationship between variables.

Table 2. Participants' Demographics

\begin{tabular}{cc}
\hline \multicolumn{1}{c}{ Data } & Freq \\
\hline Gender & $\mathbf{2 0}$ \\
Male & 7 \\
Female & 13 \\
\hline Age & $\mathbf{2 0}$ \\
$18-21$ & 4 \\
$22-24$ & 12 \\
$25-28$ & 4 \\
\hline
\end{tabular}

\begin{tabular}{cc}
\hline \multicolumn{1}{c}{ Data } & Freq \\
\hline Origin & $\mathbf{2 0}$ \\
Asia & 6 \\
U.S. & 7 \\
Africa & 1 \\
Europe & 9 \\
& \\
\hline
\end{tabular}


It can be said that most of the research subjects were female students aged over 21 and under 25 years from the European continent.

Loneliness is measured through the UCLA Loneliness Scale which consists of 20 questions with 4 alternative answers. Here is a table of results of calculations and categorization based on research data obtained from the scale of loneliness variables:

Table 3. Loneliness Scale Calculation Results

\begin{tabular}{lllll}
\hline & Mean & Max. & Min. & SD \\
\hline Empiric & 30,45 & 63 & 16 & 10,37 \\
Hypothetic & 50 & 80 & 20 & 5 \\
\hline
\end{tabular}

Hypothetical data is used as a calculation in determining the categorization of values, to obtain lonely scale categorization as follows:

Table 4. Loneliness Scale Categorization Results

\begin{tabular}{lll}
\hline Category & & Freq \\
\hline High & $x>60$ & 1 \\
Moderate & $40<x<60$ & 2 \\
Low & $x<40$ & 17 \\
Total & & 20 \\
\hline
\end{tabular}

The most frequent frequency is in a low category $(x<40)$ with a total of 17 students. Thus it can be said that most of the international students of the Darmasiswa Program YSU feel low loneliness or rarely feel lonely, but there is one international student who is in the high loneliness category.
Psychological well-being is measured through the Psychological Well Being Scale instrument which consists of 42 questions with 6 alternative answers. The following are the results of calculations and categorization based on research data obtained from the scale of psychological well-being (PWB) variables:

Table 5. PWB Scale Calculation Results

\begin{tabular}{lllll}
\hline & Mean & Max. & Min. & SD \\
\hline Empiric & 153,25 & 186 & 95 & 25,46 \\
Hypothetic & 147 & 252 & 42 & 35 \\
\hline
\end{tabular}

Hypothetical data is used as a calculation in determining the categorization of values, to obtain lonely scale categorization as follows:

Table 6. PWB Scale Categorization Results

\begin{tabular}{lll}
\hline \multicolumn{2}{l}{ Categories } & Freq \\
\hline High & $x>182$ & 3 \\
Moderate & $112<x<182$ & 15 \\
Low & $x<112$ & 2 \\
Total & & 20 \\
\hline
\end{tabular}

The most frequent frequency is in the moderate category $(112<\mathrm{x}<182)$ with a total of 15 students. Thus it can be said that most of the international students of the UNY Darmasiswa program have a moderate level of psychological well-being, but two students who have a low level.

Data from the psychological wellbeing instruments obtained were then divided based on each dimension to determine the level of categories in each dimension. Based on hypothetical data, it is known that the highest value (Max) is 42 , the lowest value (Min) is 7, the average (Mean) is 24.5 with standard deviation 5.9. Hypothetical data calculations are used to determine the value of categorization. 
Table 7. PWB's Dimensions

Categorization Results

\begin{tabular}{lllll}
\hline \multicolumn{5}{c}{ Categorization } \\
& High & Moderate & Low & \\
& $\boldsymbol{x}>\mathbf{3 0}$ & $\mathbf{1 8}<\boldsymbol{x}<\mathbf{3 0}$ & $\boldsymbol{x}<\mathbf{1 8}$ & Total \\
\hline SA & 8 & 11 & 1 & \\
PR & 8 & 11 & 1 & \\
A & 0 & 16 & 4 & 20 \\
EM & 0 & 17 & 3 & \\
LG & 0 & 15 & 5 & \\
PD & 16 & 4 & 0 & \\
\hline
\end{tabular}

It is known that most international students have the ability to self-acceptance (SA), positive relationships with others (PR), autonomy (A), environmental mastery (EM), and life goals (LG) in the medium category $(18<\mathrm{x}<30)$. There are almost no international students who have high A, EM, and LG. however, many international students can develop their personality (PD) high $(x>30)$ and there are no international students who have a low PD. Based on the categorization table above, it is known that as many as 17 out of 20 international students can master the environment (EM) moderate $(18<\mathrm{x}<30)$ where it is the highest frequency in the categorization of the dimensions of psychological well-being. It is also known that the ability to develop personality (PD) has the highest frequency in the high category $(x>30)$ that is 16 out of 20 students. As for the low category (x $<18)$, the highest frequency is in the life goals dimension (LG), which is 5 out of 20 students. Data categorization of psychological well-being dimensions is used by researchers as a support in the preparation of discussion of research results.

Data analysis was performed to determine the relationship between loneliness and psychological well-being. Data analysis using Pearson Product Moment correlation test techniques on SPSS 22.0. Following are the test results obtained:
Table 8. Results of Loneliness Correlation with PWB and its' Dimensions $(\mathrm{N}=20)$

\begin{tabular}{|c|c|c|}
\hline Variables & & $\mathbf{r}$ \\
\hline $\begin{array}{l}\text { Psychological Well- } \\
\text { Being }\end{array}$ & (PWB) &,- 152 \\
\hline Self Acceptance & $(\mathrm{SA})$ &,- 164 \\
\hline Positive Relationship & (PR) &,- 389 \\
\hline Autonomy & (A) &, 069 \\
\hline $\begin{array}{l}\text { Environmental } \\
\text { Mastery }\end{array}$ & $(\mathrm{EM})$ &,- 338 \\
\hline Life Goals & (LG) &,- 091 \\
\hline $\begin{array}{l}\text { Personality } \\
\text { Development }\end{array}$ & (PD) &, 053 \\
\hline
\end{tabular}

Based on the Table 8., it is known that the two variables have a very low relationship $(\mathrm{r}=-0.152)$. So it can be concluded that there is a negative and very weak relationship between loneliness with psychological well-being. A correlation test was also carried out on variables with each dimension of psychological well-being to find out more specifically about the relationship held by the lonely variable with psychological well-being.

Overall, the results of the calculation of lonely data with psychological well-being and its dimensions show that not all dimensions of psychological well-being have a negative relationship with loneliness in the research subjects. And the relationship between loneliness and psychological well-being in international students is not so strong as indicated by the low correlation rate.

\section{Discussion}

Based on the results of research, the loneliness and psychological well-being of international students Darmasiswa scholarship program at Yogyakarta State University in the academic year 2018/2019 has a very weak negative relationship. Research conducted using quantitative methods with the distribution of the instrument of a UCLA Loneliness Scale by Russell and Psychological Well-Being Scale by Ryff. Researchers use research from 


\section{Loneliness and Psychological .... Mawas Dwi Cahyadi}

Cenkseven (2007) and Halim (2017) research as relevant research that is a reference in conducting this research, but the results obtained are not the same as the results in relevant research. So researchers use other research to strengthen the discussion on the results of the study.

This research was conducted to determine the relationship between loneliness and psychological well-being in international students of the Darmasiswa program at Yogyakarta State University. As explained earlier that each international student has a different cultural orientation that can affect his psychological well-being (Rahayu, 2008). Being an international student also does not rule out the possibility of feeling lonely because there is no close relationship (Russell, 1980) caused by the social environment situation.

The results showed that the level of loneliness in international students had an average rate of 30.45 . Based on the data, it can be concluded that international students in the Darmasiswa program at UNY feel lonely in the low category ( $\mathrm{x}$ $<40$ ). Hypothetical data also shows that the majority of the frequency of lonely students is in a low category. The loneliness felt by international students does not escape from the factors that influence it, such as inadequate relationships, changes in relationships owned, lack of self-esteem, and poor interpersonal behavior (Brehm, 1985) where these factors are often also experienced by new students and overseas student.

The results also showed that psychological well-being in international students had an average number of 153.25 with a moderate category $(112<\mathrm{x}<182)$. The average number is also the highest frequency of subjects. Psychological wellbeing is life satisfaction, so it can be said that international $n$ students of the Darmasiswa program at UNY have moderate welfare. Previously, the results of data analysis of each dimension of psychological well-being (Table 7.) have been explained, including self-acceptance (SA), positive relationships with others (PR), autonomy (A), environmental mastery (EM), life goals (LG), and personality development (PD). Based on the results of data processing, it is known that most international students have a moderate ability to master the environment and the ability to develop high personalities, so that most of the research subjects can choose and create a suitable environment for themselves and have the potential to always develop the ability and potential he has by the objectives of international students, namely to get new knowledge.

Besides, the Darmasiswa students at UNY has a low level of loneliness. The level of loneliness is generally influenced by personality, social desirability, and depression (Russell, 1980), where it also happens to international students at UNY. Nevertheless, academic activities provided by UNY for the Darmasiswa scholarship program consist of various agendas such as language classes, sit-in classes for elective courses, cultural excursions, craft workshop classes, and others. So the desire to socialize becomes an obligation for international students because of the tight academic activities of UNY that make students social and interact with other students, lecturers, and BIPA tutors. The behavior shown by BIPA lecturers and tutors can be used as an example by international $\mathrm{n}$ students to start changing their behavior into a friendly person by with social and cultural customs in Indonesia.

Likewise, the dimensions of the psychological well-being of international students at UNY. Based on the data analysis conducted, the loneliness felt by international students of the Darmasiswa program at UNY has a negative relationship with the ability to master the environment (EM), the ability to positively relate to others (PR), self-acceptance (SA), and life goals (LG). So the higher the loneliness felt, the lower the ability of EM, PR, SA, and LG in international students, and vice versa. 


\section{Loneliness and Psychological .... Mawas Dwi Cahyadi}

However, the results of the study showed a positive relationship between loneliness with the dimensions of autonomy (A) and personality development (PD). Thus, the higher the loneliness felt, the higher the autonomy and personality development of international students, and vice versa. In general, psychological well-being is influenced by age, level of education, gender, social support, and spirituality (Ryff, 1989) which also happens to international students at UNY.

The results of the study mentioned that the relationship of environmental mastery (EM) has a significant negative correlation $(r=-0,388)$ with loneliness. So it can be said that the higher the loneliness of international students, the lower the environmental mastery ability it has. That is because international students have difficulty in regulating the surrounding life which is a different social and cultural situation. This is in line with research by Norah Aldawsari (2018) which states that in predicting the ability to master the environment in international students, social support plays a very significant role. His research shows that social support in the form of family relations, friendship or friendship, and significant others becomes a reference for international students in the country where he lives to be able to organize themselves, have the ability to adapt and deal with problems in their social sphere. This is also supported by the theory of loneliness of Bruno (2000) which describes the factors of loneliness including isolation, feeling unloved, and not having friends.

The theory emphasizes more on social conditions so that individuals with minimal social abilities have the potential to experience loneliness. Environmental mastery (EM) is the ability to manage their own lives and the lives of the world around them effectively (Ryff, 1989). International students who are unable to manage their own lives or the lives of those around them will feel lonely. Lack of ability to master the environment can be shown by the lack of social support and relationships obtained from people around them.

In another PWB dimension, the results of the study stated that a positive relationship with another person (PR) had a sufficiently negative correlation $(r=-0.289)$ with loneliness. The Darmasiswa students at UNY can establish positive relationships with other good people. The cultural differences felt by each student are what unite their goals to study Indonesia and its culture more deeply, so that international students in the Darmasiswa program of UNY establish good relations among international students as well as with lecturers, tutors, and local people they meet. This reminds researchers of the journal by Ladd Wheeler (1983) which states that the strongest prediction for loneliness is meaningful (interpersonal) interaction. Interaction meaningfulness and loneliness obtained in the study were obtained by the RIR (Rochester Interaction Record) method and the UCLA test instrument. The results show that the more meaningful an individual's social interaction, the lower the level of loneliness he has. In line with research conducted by researchers, students with low levels of loneliness tend to have the ability to deal positively with others who are high. The theory from Brehm also supports the results of this study, that good interpersonal behavior can be a factor influencing loneliness.

The results also found that selfacceptance (SA) and loneliness had a very weak negative relationship ( $r=-0,164)$. Based on this, if international students feel lonely, their self-acceptance ability decreases but does not correlate with each other. Self-acceptance owned by international students UNY Darmasiswa program can determine the loneliness experienced. Most international students of the Darmasiswa program follow an open and free western culture.

The open attitude that is owned makes international students able to accept 


\section{Loneliness and Psychological .... Mawas Dwi Cahyadi}

and understand themselves. Hurlock (1974) explains that self-acceptance is an individual's level of awareness about his characteristics and the willingness to live with these circumstances. It can be said that self-acceptance is not so influenced by external factors such as social needs or cultural customary demands, selfacceptance is more internal than the individual himself. Thus, demands and social conditions that can lead to loneliness are not a problem for international students because of their openness and acceptance.

In the last analysis, the results of the study mentioned that the relationship between life goals (LG) with loneliness has a weak negative correlation $(r=-0.091)$. It can be said that the life goals of international students have little to do with the loneliness they feel. In general, life goals do not have a strong correlation because loneliness is a feeling that arises because of the lack of social needs that are found. Nevertheless, the results of the study can show that the lower the loneliness felt by international students, the higher the life goals (LG) they have, even though the relationship is very weak.

Life goals that are owned by international students are not of concern to researchers because life goals will always change with age. International students of the UNY Darmasiswa program are of average young adult age, so their life goals are more critical about current life such as academics and making meaningful experiences. Researchers considered Gary Reken's (1987) article about the meaning and purpose of life. In his research, it was stated that the purpose of life is predicted to increase along with the functioning of age because setting life goals requires time and maturity. This was also reinforced by Ryff who explained the influence factors of Psychological well-being, namely age and spirituality.

Another article also mentions that the purpose of life is something that arises not from yourself. Developing life goals begins with passing through various kinds of observations of others (Kashdan, 2009). He stressed that the discovery of life's goals is the result of observing other people's behavior and emotional reactions that occur.

Overall research results and analysis results conducted by researchers, loneliness and psychological well-being of international students Darmasiswa program at Yogyakarta State University in the $2018 / 2019$ school year had a very weak negative relationship $(\mathrm{r}=-0.152)$. If international students experience loneliness, it does not have a strong relationship with their psychological wellbeing. There are also several dimensions of psychological well-being that have a negative relationship with loneliness, but the correlation number is minimal so it can be said that the dimension does not have a strong relationship with loneliness.

\section{Conclusion}

Based on the results of research conducted, it is known that most of the international students of the UNY Darmasiswa program in 2018/2019 have a low level of loneliness even though there is one student who has a high level of loneliness. On the other hand, most international students have a moderate level of psychological well-being.

This study found that there was a very weak negative relationship between loneliness and psychological well-being in international students of the Darmasiswa program in 2018/2019 at Yogyakarta State University. So it can be said that loneliness and psychological well-being in international students have a relationship that is not so strong. Similarly, the dimensions of psychological well-being. The results showed that some students had sufficient negative relationships (positive relationships with others; and environmental mastery) with loneliness. 


\section{Loneliness and Psychological .... \\ Mawas Dwi Cahyadi}

However, between loneliness and those dimensions has a not so strong relationship.

\section{References}

Aisah, A. dkk. (2017). Well-Being Mahasiswa (Studi Kuantitatif Deskriptif di Universitas Muhammadiyah Yogyakarta). Yogyakarta: Universitas Muhammadiyah Yogyakarta.

Aldawsari, N. dkk. (2018). The Effect of Cross Cultural Competence and Social Support on International Students' Psychological Adjustment: Autonomy and Environmental Mastery. Journal of International Student. Vol. 8 No. 2.

Arikunto, S. (2010). Prosedur Penelitian Suatu Pendekatan Praktik. Jakarta: Rineka Cipta.

Azwar, S. (2015). Penyusunan Skala Psikologi Edisi 2. Yogyakarta: Pustaka Pelajar.

Baron, R.A, \& Byrne, D. (1997). Social Psychology, eight editions. Massachusettes: Allyn and Bacon.

Baron, R.A, \& Byrne, D. (2000). Psikologi Sosial. ----

Brehm, S. S, \& Kassin, S. M. (1990). Social Psychology. Boston: Houghton Mifflin.

Bruno, F. J. (2000). Conquer Loneliness: menaklukkan kesepian. Jakarta: PT Gramedia Pustaka Utama.

Cecen, R \& Cenkseven, F. (2007). Psychological Well Being in Predicting Loneliness among University Students. C.U. Journal of Institute of Social Scieces. Vol. 16 No. 2.

Chaplin, J. P. (2011). Kamus Lengkap Psikologi. Jakarta: PT Raja Grafindo Persada. de Lazzari, S. (2000). Emotional Intelligence, Meaning, and Psychological Well Being: A Comparison Between Early ang Late Adolescence. British Columbia: Trinity Western University.

Depdikbud. (2012). Undang-Undang RI Nomor 12, Tahun 2012, tentang Pendidikan Tinggi.

Halim, C. F. \& Dariyo, A. (2016). Hubungan Psychological Well Being dengan Loneliness pada Mahasiswa yang Merantau. Jurnal Psikogenesis Fakultas Psikologi Universitas Yasri. Vol. 4 No. 2.

Hurlock, E. B. (1980). Psikologi Perkembangan Suatu Pendekatan Sepanjang Rentang Kehidupan. Jakarta: Erlangga.

Kashdan, T. B. (2009). Origins of Purpose in Life: Refining our Understanding of a Life Well Lived. Journal Psibologijske Teme. Vol. 18 No. 2.

Kamus Besar Bahasa Indonesia.

Liwarti, L. (2013). Hubungan pengalaman spiritual dengan psychological wellbeing pada penghuni lembaga permasyarakatan. Jurnal Sains dan Praktik Psikologi UMM. Vol. 1 No. 1.

Myers, David G. (1999). Psikologi Sosial. Jakarta: Salemba Humanika.

Neugarten, L. B. (1961). Life satisfaction and social interaction in the aging. Journal of Georntology. Vol. 16.

Prasetia, Dwi Nur. (2013). Hubungan Antara Kesepian dengan Penyesuaian Diri pada Mahasiswa (studi Korelasi pada Mahasiswa Tahun Pertama Fakultas Psikologi Universitas Diponegoro). Semarang: Universitas Diponegoro.

Rahayu, M. A. (2008). Psychological Well Being pada istri kedua dalam pernikahan poligami (studi kasus pada 
dewasa muda). Depok: Universitas Indonesia.

Reken, G. \& Wong, P. T. (1987). Meaning and Purpose in Life and Well-Being: a Life-span Perspective. Journal of Gerontology. Vol. 42.

Russell, D. (1996). UCLA Loneliness Scale (Version 3): Reliability, Validity, and Factor Structure. Journal of Personality Assessment. Vol. 66.

Russell, D. dkk. (1980). The Revised UCLA Loneliness Scale: Concurrent and Discriminant validity evidence. Journal of Personality and Social Psychology. Vol. 39.

Ryff, C. D. (1989). Happiness is everything, or is it? Explorations on the meaning of psychological well-being. Journal of Personality and Social Psychology. Vol 56.

Sarwono, J. (2009). Statistik itu mudah: panduan lengkap untuk belajar komputasi statistik menggunakan SPSS 16. Yogyakarta: Andi offset.

Sjostorm, O. (2002). Validity of a questionnaire survey: response patterns in deifferent subgroups and the effect of social desirability. Journal: Acta Odontologica Scandinavica. Vol. 60.

Sudjana, N. \& Ibrahim. (1989). Penelitian Kualitatif dan Kuantitatif. Bandung: Sinar Baru.

Sugiyono. (2011). Metode Penelitian Kuantitatif, Kualitatif, dan R \& D. Bandung: Alfabeta.

Ulfah, Dina Maria. (2012). Hubungan antara Penerimaan Diri dengan Persepsi Terhadap Kesepian pada Remaja yang tinggal di Panti Asuhan Darul Aitam Wadlufa'Lasem. Semarang: Universitas Sultan Agung.

Wardani, W. K. (2016). Daya Juang Mahasiswa Asing. Jurnal Ilmiah Psikologi: PSYMPHATIC. Vol. 3 No. 2.
Weiss, R. S. (1973). Loneliness: The experience of emotional and social isolation. Cambridge, MA: MIT Press.

Wheeler, L. \& Reis, H. (1983). Loneliness, social interaction, and sex roles. Journal of Personality and Social Psychology. Vol. 45.

Wijaya, R. (2013). Anxiety Uncertainty Management Mahasiswi Inholland Program Studi Manajemen Bisnis Internasional. Jurnal E-Komunikasi. Vol. 1 No. 1. 